\title{
Mitteverbaalne sündmus kui usundilise jutuloome osa ${ }^{1}$
}

Reet Hiiemäe

Teesid: Kahe või rohkema osapoolega kommunikatsioon sisaldab alati ka mitteverbaalset aspekti, seda nii info edastamisel kui ka selle vastuvõtmisel. Vaatlen oma artiklis mitteverbaalset sündmust kui usundilise jutuloome osa, kuna sellele tahule on minu arvates seni suhteliselt vähe tähelepanu pööratud. Ometi on sageli kogu folkloorse narratiivi baasiks mitteverbaalne sündmus, mis on andnud selle pealtnägijale või edasijutustajatele inspiratsiooni nähtu tõlgendamiseks olemasolevast rahvausundist lähtuvalt. Mitteverbaalset komponenti sisaldavad usundiliste juttude tekstid koosnevad seega kahest osast 1) mitteverbaalse sündmustiku kirjeldamine; 2) jutustaja poolt verbaliseeritud tähendus/tõlgendus, mis seab kirjeldatu ajastukohasesse usundilisse raamistusse. Oma artiklis vaatlen peamiselt vanema pärimuse usundiliste juttude tekste, analüüsides, milliseid seaduspärasusi võib kohata mitteverbaalse sündmuse sõnastamisel, millist rolli mängivad selle juures sündmuse toimumise kontekst (näiteks aeg ja koht) ning jututegelaste tegutsemise laad ja resultaat. Teoreetilise baasina kasutan kommunikatsiooniuurijate, narratiivse paradigma teoreetikute ja usunditeadlaste töid.

Märksõnad: jutustamine, mitteverbaalne kommunikatsioon, mitteverbaalne käitumine, usundiline jutt

\section{Sissejuhatus}

Usundiliste juttude uurimine põhineb enamjaolt jutustajate esitatud lugude tekstivormis üleskirjutustel. Ent mind huvitab selliste tekstide kujunemisprotsess, eelkõige just mitteverbaalse komponendi roll usundilises jutuloomes. Hõlmab ju kahe (või rohkema) osapoolega suhtlussituatsioon alati ka mitteverbaalse aspekti, seda nii info edastamisel kui selle vastuvõtmisel (vrd Streeck \& Knapp 1992: 3), ja sageli tundub, et kogu folkloorse narratiivi baasiks on mitteverbaalne sündmus, mis on andnud selle pealtnägijale või edasijutustajatele inspiratsiooni nähtu tõlgendamiseks olemasolevast rahvausundist lähtuvalt. Sellele tahule on seni võrdlemisi vähe tähelepanu pööratud, sest paratamatult on tehtavad järeldused mõnevõrra hüpoteetilise iseloomuga, ent sellegipoolest 
võimaldab mitteverbaalse aspekti kaasamine usundilise jutu uurimisele terviklikumalt läheneda, tõotades vähemasti heuristilist lisaväärtust. Ma ei püüa järgnevas rekonstrueerida täpseid algsituatsioone, mille põhjal usundilised jutud on tekkinud, vaid minu eesmärk on eelkõige vanema pärimuse näidetele tuginedes osutada seaduspärasustele, mida võib mitteverbaalse sündmuse sõnastamisel täheldada, ning asjaoludele, miks need jutud just sellisena on traditsioonis püsinud. Vaadeldud usundilised jutud pärinevad Eesti Rahvaluule Arhiivi käsikirjakogudest. Ühtlasi püüan vastata küsimusele, kuivõrd on kommunikatsiooniteooriaid ja narratiiviteooriaid ühitades ning neid konkreetsete arhiivitekstide puhul rakendades mitteverbaalse aspekti uurimine usundiliste juttude kontekstis üldse võimalik ja tulemuslik.

\section{Mitteverbaalne kommunikatsioon ja narratiiviuurimine: teoreetilised lähtekohad}

Mitteverbaalse kommunikatsiooni definitsioone on välja pakutud sellest ajast peale, kui see termin 20. sajandi keskpaigas laiemalt tuntuks sai (Eesti kontekstis nt Kimmel-Tenjes 1993: 536jj). Mitteverbaalse kommunikatsiooni all mõeldakse enamasti kõiki infoedastamisviise, mida kasutatakse inimeste vastasmõjuga suhtlemise ajal lisaks sõnalisele osale. Nende puhul kasutatakse vahendajana žeste, näoilmet, kehaosade asendit, liigutusi ja hoiakuid, puudutusi ning lisaks teabe selliseid aspekte, mis on tajutavad öeldu sisuga kokkusobimatuna (vrd Kendon 1981: 4). Juba mõningates sotsiaalteaduste klassikute töödes on mainitud tahtlikke sümboolseid žeste ning kirjeldatud neid keelelisele väljendusele eelneva eneseväljendusviisina (nt Durkheim [1895] 1982: 57jj). Ka uuemates kommunikatsioonialastes uurimustes rõhutatakse, et mitteverbaalse suhtluse käigus toimub teabevahetus lisaks sõnadele kõikides modaalsustes, kusjuures enamik mitteverbaalset kommunikatsiooni toimub samaaegselt verbaalsega ja on taotluslik (Giri 2009: 690).

Valdavalt keskenduvad kommunikatsiooniteooriad vahetu suhtlemise aktidele, mitte mitteverbaalsuse kajastumisele kirjapandud tekstis, ammugi veel üleloomulikku komponenti sisaldavates rahvajuttudes (kuigi paaril juhul on definitsioonides liigitatud mitteverbaalse kommunikatsiooni alla siiski ka ekstrasensoorsed tajumused, vrd nt Calero 2005: 280). Seetõttu ilmneb arhiivitekstide uurimisel nimetatud definitsioonide valguses ootuspäraselt mõningaid kitsaskohti, näiteks tekitab raskusi usundilistes juttudes kirjeldatud telepaatiliste kontaktide määratlemine. Eelkõige memoraadivormis lugudes on levinud motiiv, mille kohaselt surnud lähedane (näiteks ema) annab oma elavale lähisugulasele (näiteks tütrele) ilmumisega märku, et kedagi elavatest 
ähvardab oht. Otsest verbaalset sõnumiedastust selliste kogemuste ajal sageli ei toimu. Inimkogu nägemuslikku tajumist, mida tõlgendatakse surnud lähedase hoiatusena, saab küll käsitada teatava mitteverbaalse kommunikatsiooni aktina, kuid sellesse kätketud teabe lahtikodeerimine toimub täielikult teabe vastuvõtnud üksikisiku peas (mitme tunnistajaga juhtumeid esineb harva). Seega ei saa siin rääkida taotluslikult väljasaadetud sõnumist, vaid ainult teabe vastuvõtja tõlgendustest, mida ta oma kogemust verbaliseerides esitab.

Niisiis võib öelda, et kui kommunikatsiooniteooriates eristatakse suhtlusprotsessist rääkides teabe saatjat ja vastuvõtjat (kellest esimene edastab teavet ja teine tegeleb selle vastuvõtmise ja vastuvõetu töötlemisega), siis käesoleva artikli kontekstis on selle kahetise eristuse väljatoomine asjakohane eelkõige osutamaks tõsiasjale, et kummagi osapoole käsutuses olev info võib olla vägagi erineva kvaliteediga, kusjuures mitteverbaalsel sündmusel põhinevate usundiliste juttude puhul on sageli võtmeroll just teabe vastuvõtjal. Ka sotsioloog Niklas Luhmann omistab oma kommunikatsioonikäsitluses olulisemat rolli teabe vastuvõtjale, kuna vastuvõtja on see, kes määrab, kas ja kuidas teabe liikumine üldse aset leiab (Luhmann 1984: 191jj). Ehk siis käesolevas artiklis vaadeldud materjali kontekstis võib öelda, et vastuvõtja võib vahel vastu võtta teabe, mida pole üldse välja saadetud, või siis väljasaadetud teavet mitte märgata või mitte mõista. Väidetav pealtnägija või jutustaja määrab ka jutus kirjeldatud isikute staatuse, liigitades nad vastavalt üleloomulikeks olenditeks, maagilise rituaali läbiviijateks, tavainimesteks vms. Kuna minu kirjeldatud juhtudel on aktiivsem pool teabe vastuvõtja, olen vältinud saatjapoolse aktiivsuse aspekti rõhutamist ja kasutanud termini "mitteverbaalne kommunikatsioon" asemel pigem sõnapaari "mitteverbaalne sündmus", "mitteverbaalne käitumine" või "mitteverbaalne situatsioon", et hõlmata ka sellised tegevusviisid, mis ei sisalda sihiteadlikku teabeedastust (näiteks juhtudel, kui inimene ei teagi, et keegi teda jälgib ja tema mitteverbaalset käitumist maagilise rituaalina tõlgendab).

Siinkohal väärib märkimist, et mitteverbaalne käitumine toimub põhimõtteliselt kogu aeg - isegi täielikku liikumatust ja vaikimist on võimalik käsitada mitteverbaalse teabena, ja eelkõige just usundilises kontekstis võib vaikimine olla vägagi kõnekas. Seega sisaldavad inimkontaktid üldjuhul mitteverbaalset teavet rohkemgi kui verbaalset. Tõika, et inimene ei saa lakata oma käitumisega mitteverbaalset teavet edastamast ka parima tahtmise korral ning et info, mille põhjal inimaju otsuseid teeb, on ülekaalukalt mitteverbaalne, on konstateerinud mitmed kommunikatsiooniuurijad (Weisbuch \& Ambady 2008: 163-164; Giri 2009: 690). Just seetõttu on huvipakkuv ka mitteverbaalse komponendi kaasamine usundiliste juttude uurimisse. 


\section{Mitteverbaalsus ja usundilised jutud: folkloristide tööd}

Oma 1960. aastatel ilmunud uurimuses mängude kui mitteverbaalse folkloori kohta märgib folklorist Alan Dundes (2007), et rääkides vaimsest kultuuripärandist mõeldakse eelkõige sõnalist folkloori ja uuritakse tekste, kuid uurida tuleks ka mitteverbaalseid folkloorivorme, kuna need on struktuurilt sarnased. Nüüdseks on Eestis ilmunud mitteverbaalsete folkloorinähtuste kohta mitmeid uurimusi (näiteks pärimustantsu kohta Kapper 2013, piltmõistatuste ja grafiti kohta Voolaid 2011: 35). Narratiivse folkloori puhul on jälgitud mitteverbaalse kommunikatsiooni ja multimodaalsuse aspekti eelkõige folkloori esituse juures (näiteks Voolaid 2011: 36), kusjuures multimodaalse kommunikatsiooni all mõistetakse siinkohal suhtlust, mis sisaldab rohkem kui kahte sensoorset modaalsust (keelelisi, tegevuslikke, meeltega tajutavaid aspekte) (terminist pikemalt vt Tenjes 2014: 116). Seega on terminid multimodaalne ja mitteverbaalne osalt kattuvad, ent kuna käesoleva uurimuse fookuses on eelkõige sõnastatud jututeksti ja mitteverbaalse sündmuse vastastikmõju, lähtun järgnevas terminist "mitteverbaalne".

Põhjalikumalt mitteverbaalse sündmuse ja usundilise jutuloome seostega tegelevaid uurimusi on vähe. Painajafenomeni uurinud David Huffordi (1989) teooria, mille kohaselt üleloomulikku kogemust kirjeldava rahvajutu baasiks on tegelik kogemus, mis verbaliseeritakse olemasolevas pärimuses lähtuvalt väljakujunenud sõnastamis- ja kirjeldusviisist, kehtib muuhulgas ka mitteverbaalsete kogemuste puhul. Madis Arukask osutab otseselt rahvajuttudes kajastuva eksimiskogemuse algsele mitteverbaalsele olemusele: "Sõnade kaudu väljendatav on vaid peegeldus millestki mitteverbaalsest - aistingulisest, kehalisest" (Arukask 2003: 98). Etnoloog Jelena Novik kirjeldab ümbrusest kuuldud akustiliste signaalide (nt tule praksumine, linnuhääled) tõlgendamist endemärkidena Siberi rahvastel ja järeldab, et heli, mida interpreteeritakse, võetakse kommunikatsioonina selle sõna interaktsioonilises tähenduses, st heli tekitaja kavatsusena anda edasi mingit teavet või põhjustada vastureaktsiooni. Ka Noviku uuritud jutustuste puhul saab rääkida eelkõige teabe vastuvõtjapoolsest tõlgendusest. Mitteverbaalsel elemendil baseeruv jutuloome toimib ka siin, kuna akustiline detail võib saada süžeeliselt organiseeritud teksti või selle fragmendi tuumaks (vrd Novik 2002: 107). Käesolevas artiklis ümbruskonna mitteverbaalsete signaalide endemärkidena tajumist siiski põhjalikumalt ei vaadelda, vaid keskendutakse kahte või rohkemat isikut hõlmavatele mitteverbaalse käitumise olukordadele.

Juha Pentikäinen leiab oma rahvajutu suulist esitust käsitavas töös Dell Hy-

mesile viidates: "Interaktsioon verbaalsel tasandil ei ole võimalik, kui jutustaja 
ja kuulaja teineteist ei mõista; see tähendab, kui neil puudub ühine lingvistiline ja paralingvistiline kood" (Pentikäinen 1978: 242). Tuleb rõhutada, et mitteverbaalse suhtluse puhul on jagatud keeleline ja paralingvistiline kood õigupoolest olemas, ent just selle ühise koodi tõttu (mis väljendub näiteks mitmesuguste tavaelu nähtuste kirjeldamises maagilises võtmes) saab võimalikuks ka usundiline (vääriti)tõlgendamine. Öelduga haakub narratiivipsühholoogiat uurinud Daniel Hutto märkus: "Narratiivid toimivad normaliseerivate seletustena ja võimaldavad meil toime tulla ebatavaliste või ekstsentriliste olukordadega, asetades need - kui võimalik - konteksti, milles need muutuvad mõistetavaks" (Hutto 2008: 7). Silvi Tenjes osutab inimtaju kalduvusele liigitada saadud teavet tüüpidesse ja kategooriatesse: "Kui inimene seisab silmitsi uue objekti, situatsiooni või probleemiga, siis ta seostab seda oma teadmistega, et seda mingisse tüüpi klassifitseerida. Olles nüüd objekti, situatsiooni või probleemi mingisse tüüpi liigitanud, hakkab inimene kasutama selle tüübiga seotud teadmisi selleks, et määratleda, kuidas objektiga või probleemiga ümber käia, kuidas uues situatsioonis käituda" (Tenjes 2004: 155-156). Niisiis toimub mitteverbaalse käitumise mõistmine kogeja varasema, valdavalt verbaliseeritud vormis omandatud usundilise teadmuse valguses. Muuhulgas sõltub mitteverbaalse tegevustiku tõlgendamisviisist isegi selle põhjal kujuneva narratiivi žanr: kui kogetut tajutakse lihtsalt rumala käitumisena, võib selle põhjal verbaliseeritav narratiiv liigituda pajatuseks või naljandiks, ent kui seda tajutakse maagilise ohuna, võib see ringlusesse jõuda pigem usundilise jutuna.

\section{Teekond mitteverbaalsest sündmusest sõnastatud narratiiviks}

Kognitiivse psühholoogia uurija Jerome Bruner on ühena paljudest sõnastanud jutu-ja mälu-uurimiseski asjakohase väite, et inimesed korrastavad oma kogemusi ja mälestusi narratiivselt - lugude ja uskumuste konventsionaalses vormis (Bruner 1991: 4-5). Walter Fisher, üks narratiivse paradigma teooria loojaid ja alustalasid, läheb veelgi kaugemale, väites, et igasugune kommunikatsioon on oma olemuselt narratiivne, kuna jutustamine loob inimkogemusele struktuuri ja suunab inimesi kujundama sellele ühiseid seletusi ja arusaamu. Jutustamist (narration) defineerib Fisher oma teooria raames kui "sümboolseid tegusid sõnu ja/või tegusid - millel on loogika ja tähendus nende jaoks, kes elavad neid läbi, loovad või tõlgendavad neid" (Fisher 1987: 58). Kuigi Fisheri teooriat on süüdistatud liigses üldistamises (nt Benoit 1988: 536), on see käesoleva artikli kontekstis asjakohane selles mõttes, et aitab näitlikustada tegevuse (ehk täpsemalt öeldes: mitteverbaalse käitumise) ja usundiliste juttude vastastikmõju. 
Usundiliste juttude puhul saab mitteverbaalsest sündmusest lähtuvalt välja tuua kaks mõistmise tasandit:

1) tekstis kirjeldatud mitteverbaalne sündmustik,

2) informandi poolt selgelt välja öeldud tähendus/tõlgendus kirjeldatud sündmuste kohta.

Narratiivi olulise kriteeriumina on Fisher esile tõstnud selle sisemist koherentsust ja loogilisust - jutustaja peab narratiivi jutustamisväärseks, kui ta tajub seda koherentsena, kusjuures vajalik on koherentsus nii jutumotiivide kui tegelaskujude osas (Fisher 1987: 58). Usundilise pärimuse uurimise kontekstis tundub õigustatud väita, et mitteverbaalse sündmuse prenarratiivne tõlgendamine käib usundilise ja narratiivse koherentsuse analoogiast lähtuvalt. Kogeja sõnastab oma kogemuse sõltuvalt sellest, milliste varemkuuldud uskumustega haakuvalt tundub kogetu koherentne. Kogetava automaatne võrdlemine varasemast tuttavate uskumuste/uskumusjuttudega viib selleni, et nähtu liigitatakse kõige sarnasemate tundemärkidega uskumusfenomeniga samasse klassi ja kirjeldatakse seda vastavalt, lisades vajadusel juurde toimunu mõistmiseks vajalikud puuduvad detailid. Ka folklorist Laura Stark osutab narratiivse sidususe järgimisele, märkides et me kohandame oma kogemusi vastavalt tegelaskujudele, mis on meie kultuuris üldse narratiivselt võimalikud, ning lähtume stereotüüpidest ja jutusüžeedest, mida ka meie kaasinimesed on võimelised ära tundma (Stark 2015: 118).

Siiski ei ole narratiivi koherentsuse reeglid usundiliste juttude puhul läbivalt absoluutsed, vaid näivad olevat vastastikmõjus konkreetse kogemuse või situatsiooni nõudmistega, näiteks ohu suuruse tajumisega. Järgmises näitetekstis toimib mitteverbaalse teabena visuaalse märgi puudumine - nimelt saab kogeja oma kahtlusele, et kohatud tõllassõitja oli üleloomulik olend (täpsemalt vanapagan), kinnitust jälgede mitteleidmisest, mida on usundilistes juttudes üleloomuliku olendi tunnusena korduvalt mainitud.

Kõost Käusaare metsa maantiid mööda läinud mölder kord, vana Käusaare Jaan. See läinud mööda teed ja näinud, et neli halli olnud ees ja läinud mööda Joosta teed alla, aga Käusaare Jaan mõtelnud, mis see ometi on, et nii suure hobustega ja ilusa tõllaga sinna alla sõidab. Ja läinud sinna tee peale ja vaadanud jälgi, aga ei ole mitte jälgi leidnud. Siis pannud ta imeks ja saanud aru, et see muud ei olnud kui vanatont ise (E 29140 (37) < Pilistvere khk, 1896).

Erinevalt eeltoodud näitest on järgnevas tekstis kommunikatiivseks vihjeks, mis reedab, et naist külastasid vanapagan ja naise surnud mees, just jälgede 
olemasolu ning assotsiatsioon kujutelmaga, et kuradi ühe või mõlema jala otsas on kabi (või ka sõrg).

Ennevanasti elanud Salmistu külas üks naine. Selle naise mees olnud surnud. Ühel õhtul tulnud sellele naisele võ̃oraid. Võõrad olnud toas, kuna naine teises toas toimetas. Pärast tulnud naine tuppa. Siis kui võerad ära läinud, läinud ka naine neid saatma. Teised oodanud kodu tulema, aga naist ei ole tulnud. Hommiku, kui naise vanemad merele läinud, leidnuvad nemad naise võrgust. Päevavalges vaadates näinud nemad muda peal naise jälgi ja hobusekabja jälgi. Viimaks ütelnuvad teised, et tema mees oli põrgusse läinud ja sealt vanapaganaga naise järel tulnud (E $51392<$ Kuusalu khk, 1921).

Usundiliste juttude tekste lugedes näib, et esmane mitteverbaalse teabe töötlus toimub baaskriteeriumide: võõras-tuttav, üleloomulik-loomulik, ohtlik-mitteohtlik baasil. Seda oletust toetab ka kommunikatsiooniuurijate Charles Bergeri ja Richard Calabrese ebakindluse vähendamise teooria (uncertainty reduction theory), mille kohaselt eriti just tundmatut kohates jälgib kogeja esmalt uustulnuka mitteverbaalset käitumist ja prognoosib selle põhjal, mida temalt järgnevalt oodata (1975: 99jj). Omaaegses paikse eluviisiga külas oli võõra kohtamine võrdlemisi harv nähtus ja usundilised jutud tingisid eelhäälestuse, et just võõras võib osutuda ohtlikuks või üleloomulikuks või mõlemaks korraga (vrd võõra tajumisest ohuna ja üleloomuliku olendina ka Blacker 1990: 162). Näiteks on rahvajuttudes nii katkuvaimu kui kuradit sageli iseloomustatud epiteediga “võõras". Seega toimis võõraksolemine juba iseenesest mitteverbaalse teabena ning ajendas umbusklikku ja isegi vaenulikku suhtumist veel enne, kui saabunu jõudis midagi teha või öelda. Kuid enne, kui ma vaatlen lähemalt võõraksolemisega seotud usundilisi tõlgendusi, on asjakohane lisada mõned märkused veel ühe mitteverbaalse kommunikatsiooni liigi - nimelt vaikimise - kohta, kuna vaikimisel võib usundilisest aspektist vaadatuna olla eriline kommunikatiivne roll.

\section{Vaikimine kui kommunikatsioon}

Vaikimine, teatud asjade või olendite nimetamise tabu, verbaalse kontakti vältimine teatud olukordades - need kõik on eesti rahvausundis tuntud praktikad, mida tuli järgida eriti seoses kindlate ajaperioodidega (nt epideemiate ajal ja aastaringi tähenduslikel aegadel), maagiliste rituaalidega (nt tulevase ennustamine) või kohtades, kus oli eeldatav maagilise mõju ilmnemine (nt üksi metsas). Loomulikult oli ka rohkelt selliseid rituaale, mille juurde kuulus loit- 
sude või muude sõnavormelite kuuldav lausumine, kuid viimastel puhkudel polnud interpretatsiooniraamid nii avarad. Seevastu vaikimise olukorrad pakkusid vägagi ambivalentseid tõlgendamisvõimalusi, eriti juhtudel, kui sündmustikku oli segatud mõni tundmatu, ent ka tuttavate isikute arusaamatu vaikiv tegutsemine suurendas üleloomuliku tõlgendamise tõenäosust. Eesti (ja ka paljude muude maade) rahvausundi kohaselt peeti verbaalse kontakti loomist üleloomuliku olendiga ohtlikuks, seega oli ebaselge staatusega isikut kohates omakorda eelistatav vaikimine ja tema mitteverbaalse käitumise jälgimine, et selgitada välja tema edasised kavatsused või lasta käiku ennetavad kaitsemeetmed. Järgnevas näitetekstis tõlgendatakse kaasinimeste vaikimist kurjahaudumisena, mistõttu kogeja ründab vaikijaid ennetavalt esimesena, virutades neile malgaga.

\section{Varjumehed}

Kord tulnud üks mees kõrtsist. Näinud äkiliselt, et kaks tema tuttavat, kes sugugi kõrtsis ei olnud, temaga seltsis käinud. Mees teretanud neid, need ei ole aga tervist vastu võtnud. Mees katsunud muud juttu teha, aga naabrid ei ole talle sõnagi vastanud. Nüüd arvanud mees, et naabrid mingi kurja mõttega tema ligi käivad, haaranud malga maast ja löönud mõlematele. Aga malk oli nagu õhust läbi käinud. Nüüd tulnud mets ja mehed olid meie tutva juurest metsa ära kadunud, kuna see aga kodu poole läks. Oma arvates pidi mees ammugi kodu saama, aga marssis kuni kukelauluni. Siis alles nägi mees oma maja ja sai aru, et ta neli kord ümber oma õueaja oli käinud (E 27327 (82) < Tartumaa, 1896).

Peale pealkirjas sisalduva vaimumaailmale viitava nimetuse "varjumehed" jutus sõnaselget üleloomulikku tõlgendust ei esitata, kuid spetsiifilised motiivid - "malga kehast läbiminek", "meeste metsa ärakadumine" - on omased traditsioonilisele vaimolendite kirjeldamisele, kukelauluni marssimine ja oma kodu mitteäratundmine aga üleloomulikule eksitamiskogemusele.

Jutu alguses mainitud kõrtsist tulemine annab vihje, et kogeja võis olla purjus ja seega muutunud teadvusseisundis. Purjusolekuga võiks olla seletatav ka asjaolu, et kõrtsisttulija naabrimeestele malgaga pihta ei saanud ("malk oli nagu õhust läbi käinud") ja hiljem teel ära eksis. Kui oletada, et kõrtsisttulijaga koos kõndinud mehed siiski olid tema naabrid, võis nende äkiline lahkumine olla tingitud mitte nende üleloomulikust olemusest, vaid hoopis sellest, et nad ei soovinud tülinorijaga koos edasi minna. Igal juhul nõustun Aado Lintropiga, kes märgib, et teadvuse muutunud seisundi korral aktualiseerub pärimuslikul teel edastatavatest usundilistest kujutelmadest lähtuv reaalsusorientatsioon (Lintrop 2014: 16-17). 


\section{Võõrad ja võõraste rollid usundilistes juttudes}

Folkloorinähtuste levimise ja traditsioonis püsimise tagab muuhulgas nende avatus kogejate-vahendajate-kuulajate erinevatele interpretatsioonidele. Mitteverbaalse käitumise puhul on usundiline tõlgendamisruum veelgi laiem. Järgnevalt vaatlen võõraste liigitamist katkumuistendite näitel. Muistendite järgi ilmus katkuvaim enamasti inimolendi kujul, kes kandis täiesti tavapäraseid riideid ja nägi välja nagu iga teine inimene - miski tema välimuses ei reetnud tema ohtlikku loomust (vrd sarnane märkus seoses kuradiga Valk 1994: 19). Mõnikord on usundilistes juttudes püütud siiski eristada üleloomulikke olendeid inimestest värvisümboolika alusel, näiteks väites, et katk ja kurat käisid ringi mustas, vaime ja kummitusi on aga kujutatud halli või valgena. Ent tuleb lisada, et ka tavainimeste toonane riietus oli üldjuhul samades toonides. Seega oli ainus ettevaatusele manitsev moment selliste tegelaste juures see, et nad olid võõrad. Külarahvast võisid tõepoolest nakatada juhuslikud läbirändajad või põgenikud, seega kui võõra saabumisega külla kaasnes inimeste haigestumine, oli ootuspärane tema liigitamine negatiivsesse staatuseklassi. Samas esineb katkumuistendites ka neutraalse või positiivsena kujutatud võõraid, keda on kirjeldatud kui juhuslikke öömajalisi, kerjuseid, abilisi vms - kokkuvõttes võis samasugune välimus viidata ühteaegu neljale erinevale staatusetüübile:

1) katkuvaim;

2) katkukuulutaja;

3) katkukülvaja (vähestel juhtudel kujutatud ka tuttava inimesena);

4) katku vastu aitaja.

Kõik neli on muistendites seotud katkuepideemia saabumisega, nende erinev staatus ilmneb alles edasise tegevuse käigus (kerjuspoiss hakkab kepiga inimesi torkama, tundmatu teekäija annab nõu jne), kuid nii mõnelgi korral otsustatakse võõraste staatus kohe nende ilmudes.

Võõraste staatuse määrab sündmuse väidetav pealtnägija või jutustaja (vrd sarnane tähelepanek võõra tõlgendamise kohta üleloomuliku olendina Valk 2015: 426). Nii näiteks klassifitseeritakse järgmises tekstis üks poistest katkuks ja teine heatahtlikuks abiliseks:

Rummu mõisahärra annud ennevanasti teada, et katk tuleb Neeme külasse. Ta käskinud inimesi ennast puhtaks pesta ja ennast täiesti surmale valmistada. Ühte perre tulnud üks kerjuspoiss. See poiss on palunud öömaja. Sealtpere inimesed on ütelnud sellele poisile, et nemad hakkavad surema ja nemad ei saa kellelegi öömaja anda. Poiss on palunud ikka, et teda võetaks, siis jäävat kõik ellu. Viimaks pererahvas jätnud. 
Katk pidi tulema ühe poisikese näol. See poiss oli mõisahärra poolt saadetud. Tal oli kepp käes, mille otsas oli mürki. Kui see katkupoiss sinna perre akna kaudu tuli, karanud kerjuspoiss ja tapnud katkupoisi ära. Nii jäid kõik ellu (Hiiemäe 1997: 284).

Tundub, et jutustaja pole eeldanud, et tema auditoorium vajaks selgitust, miks ei peetud esimest poissi katkuks, kuigi oli ette teada, et haigus liigub just võõra poisi näol. Tegelase staatus oli lahtine ning seega vabalt täidetav. Esimesele võõrale poisile omistatakse katku eest kaitsja roll, misjärel temast saab positiivne karakter. Seevastu teine poiss lüüakse kohe maha, ilma et peetaks vajalikuks lähemalt selgitada, kas ta tõepoolest kavatses haigust külvata või oli samasugune rändav kerjuspoiss nagu esimenegi.

Võib oletada, et ohuolukorras võisid inimesed ka tegelikult tundmatusse isikusse projitseerida rohkem kui ühe rolli, mis samas ei välistanud isegi rollide täielikku vasturääkivust (Hiiemäe 2007: 204). Niklas Luhmann märgib kommunikatsiooniaktist arusaamise valikulisust kommenteerides, et iga valik on kontingentne ehk ka teisiti võimalik, seega on valikute hulk teoreetiliselt lõputu (Kõuts-Klemm 2007: 2429). Usundilises pärimuses (ja tõenäoliselt ka muudes kontekstides) tegelasrollide täitmise võimalused päris lõputud siiski ei ole, sest valik peab olema situatsioonisidus (ehk antud juhul: haakuv tõdemusega, et võõraste küllasaabumine võis tõepoolest põhjustada inimeste nakatumist) ja usundiliste juttude kontekstis ka usundi seisukohalt koherentne (ehk antud juhul: haakuv seisukohaga, et haiguse levikut saab peatada haigusvaimu mahalöömisega). Küll aga on asjakohane Luhmanni väide keskkonnast tulenevatele mõjutustele tähenduste omistamise kohta, nimelt võimaldab see "kas lükata oma reaktsiooni edasi või reageerida peaaegu silmapilkselt, sest juba läbielatud sarnastest olukordadest on võimalik üle võtta varem juba kasutatud ning end õigustanud reaktsioon" (Luhmann 1997: 45-46). Usundiliste juttude puhul lisandub olukordadele tähenduse omistamisele ka pärimusliku legitiimsuse aspekt, mis õigustab ka üldiste moraalsete tõekspidamiste seisukohalt mittelubatavad teod (nt vägivalla või isegi tapmise).

\section{Mitteverbaalne käitumine ja vägivald}

Kui mitteverbaalseid signaale tajutakse liialt ohustavana, on usundiliste juttude tegelaste reaktsiooniks kaitsemaagia kasutamine või pahatihti lausa füüsilisse konflikti astumine. Märkimisväärselt palju leidub juttudes kirjeldusi olukordadest, milles kogeja asub mõne kaaskodaniku mitteverbaalset käitumist jälgides teda füüsiliselt ründama, nagu näiteks järgnevas jutus. 
Siin vana köstri juures keidud öösi lambaid salaja niitmas. Vanamees, nui kätte ja küinal vaka alla - ja valvama. Karjauks teind kääksti, tulndki. Lammad joosnd mürrdi teise nurka kokku. Eidel käärid kääs naksti, naksti. Vanamees lükand vaka küindla pealt ära, et valgem oleks ja tümmeldand teise vaeseomaks. Äi põle isi oma jalaga laudast välla $k a$ saand, vanamees lohistand ta ukse taha ja läind isi tuppa magama.

Pool aastat olnd eit peale seda põhkus, kellele sa tohid reekida, mis sa tegid (ERA II 254, 91/2 (29) < Käina khk, 1939).

Ülaltoodud tekstis kirjeldatav eit ei ütle kogu jutu jooksul, milles kirjeldatav ajaline raam kestab pool aastat, ainsatki sõna, ammugi ei kommenteeri ta oma tegevust, kuid sellegipoolest on tema tegu kirjeldav jutt vägagi kujundlik ja ilmekas. Tegemist on nähtusega, mille kohta Laura Stark kasutab terminit narratiivne hääletus (voicelessness) ja millel on rahvajutus oma retooriline funktsioon: rahvajutud sisaldavad teatud tüüpi tegelaskujusid (nagu näiteks väidetavad maagia toimepanijad ja teised ühiskonna normidele mittevastavalt käituvad isikud), kes kunagi ise endast ei räägi, vaid kellest räägivad ainult teised (vrd Stark 2015: 118jj). Ülaltoodud tekstis ei lisa õigupoolest küll ka jutustaja ise selget tõlgendust, miks eit tema arvates lambaid pügamas käis. Juhul, kui eit oleks kasutanud tõepoolest kääre, mitte lambaraudu, ei oleks saanud pöetud villa kogused igatahes olla nii suured, et sellest tulenev otsene majanduslik kahju oleks nimetamist väärinud. Samal ajastul käibelolnud maagiliste uskumuste kohaselt võidi minna öösel võõrasse lauta villa pügama nii kahjustaval kui ka mittekahjustaval eesmärgil, näiteks 1) selleks, et ära võtta sealset lambaõnne, 2) selleks, et valmistada kiiret mehelesaamist tagavat riideeset (ese pidi sisaldama ühes kuni üheksas võõras laudas lammastelt pügatud sümboolse koguse villa), 3) selleks, et valmistada kohtus õiguse saamist kindlustavaid kindaid (selleks pidi eelkõige vastlaööl üheksast laudast toodud villast kindad kuduma ja need kohtus kätte panema). Põhimõtteliselt oli - taaskord mitteverbaalsele teabele tuginedes - võimalik osa tõlgendusvariante välistada: eeldatavasti ei olnud parasjagu vastlaöö (jutu järgi oli villa pügatud rohkem kui ühel ööl) ja samuti ei olnud eit ilmselgelt meheleminekuealine. Ent mõningate tekstide kohaselt võis meheleminekut soodustavaks rituaaliks vajalikku villa käia hankimas ka neiu ema, seetõttu eide vanus seda varianti veel ei välistanud. Siiski on kahtlane, kas vanamees oleks suutnud eide sisenemise ja rünnaku vahele jääva lühikese hetke jooksul olukorda nii põhjalikult analüüsida, kindlam oli reageerida ohu kahtlusel kohe vägivallaga. Usundilise tõlgenduse seisukohalt toetas toimunu maagilist seletamist ka sündmuse ajaline raamistus - nimelt öine aeg. 


\section{Sündmustiku ajaline ja ruumiline mõõde kui mitteverbaalne teave}

Mõned kommunikatsiooniuurijad lisavad oma definitsioonides, et mitteverbaalseid "sõnumeid" saab edastada ka keskkond, ning arvesse tuleb võtta samuti ajalist mõõdet (nt Kendon 1981: 5; Giri 2009: 693). Usundiliste juttude mitteverbaalse aspekti mõistmisel on toetavaks tõlgendusraamiks usundilises mõttes tähenduslik ajaline või ruumiline kontekst. Kui elava traditsiooni keskkonnast pärit inimene siseneb sellisesse mütoloogiliselt laetud sfääri (nt öine aeg, tabuline või kriitiline periood, eriline koht, näiteks mõni vaimude ilmumise või maagiliste toimingute paik), tingib tema vastav eelhäälestus hirmu intensiivistumise ja valmiduse kokkupuuteks üleloomulikuga. Tõenäoliselt põhjustas see katkuaegadel inimeste kõrgenenud vastuvõtlikkuse teatud isikute või rühmade interpreteerimiseks mütoloogiliste olenditena (vrd Hiiemäe 2007: 201) ning samalaadsed ruumilised ja ajalised komponendid võisid soodustada kaasinimeste tõlgendamist maagiliste kahjustajatena. Siin saame rääkida kultuurilise etteantuse mõjust, mida on analüüsinud mitmed folkloristid (näiteks Honko 1972; Laagus 1973: 407-409), ehk - kommunikatsiooniteooria vaatenurgast keskkonna edastatud "sõnumist".

Lauri Honko osutab, et memoraadis esitatud üleloomuliku kogemuse puhul tuleks lisaks arvesse võtta üleloomuliku kogemuse liiki (visuaalne, auditiivne, taktiilne või nende kombinatsioon) ja tajumise tingimusi (pimedus, hämarus, monotoonsete ärritajate mõju, kogeja seisund, näiteks haigus, üleväsimus, purjusolek, tugeva hirmu või soovimise seisund) (Honko 1972: 95-96). Aado Lintrop märgib lisaks ära usundiliste tabude vastu eksija ootuse lubamatu teo karistatavusele osutava üleloomuliku kogemuse ilmnemiseks: "Traditsioon annab ajendi või põhjuse kogemuse formeerumiseks, näiteks mingi normi vastu patustanud inimene ootab üleloomuliku olendi kui korralekutsuja ilmumist ja on aldis nähtud kogu sellena tõlgendama" (vrd Lintrop 2014: 17). Seega on vastavalt usundilisele pärimusele ka vaimolenditel oma staatus, oma õigused ja kohustused; neilt oodatakse teatavat käitumist, mis üleloomulikuna tajutud situatsioonis aktualiseerubki (vrd Laagus 1973: 408).

Järgnevas näitetekstis piirdub mitteverbaalne komponent auditiivselt tajutud heliga. Loo puhul torkab toimunu usutavuse suurendamise taktikana silma meeste nimede nimetamine.

Kord läinud P. Jüri ja K. Jaan kuusemetsa palgivargille ja hakanud metsas palka raiuma, nii et laastud lennanud kohe. Ja kui see kuusk maha saanud lastud, siis hakanud ta teist kohe raiuma ja annud kuusele. Ja see olnud neljapäeva õhtul. Aga mehed jäänud kuulatama ja kaugelt 
olnud nagu hobusekabjade plaginat. Ja see plagin tulnud ikka ligemalle. Ja ikka plagin tulnud ikka ligemalle. Meestel hakanud kangesti hirm ja näinud, et kõik mets läinud sealt valgeks ja see ragin tulnud ligemalle. Mehed aga karanud regede peale ja ajama hobustega Unakvere poole ja ei ole enam julgenud tagasi minna (E 29130 < Pilistvere khk, 1896).

Maagiliselt laetud ajal (neljapäeva õhtul) lubamatu teo tegemine ja sellega kaasnev hirmutunne korreleeruvad kuuldud heli tõlgendamisega üleloomuliku korralekutsuja funktsioonis. Eelhäälestus üleloomuliku sekkumise avaldumisele välistab võimaluse, et kuuldud plaginat tõlgendataks teiste omasuguste, näiteks samuti metsavargil olevate inimeste tekitatud helina.

\section{Jutustaja tõlgenduse autoriteetsus}

Kui suhtlusaktis on kaks teineteisele nähtavat osapoolt, siis dekodeerivad nende mitteverbaalsest käitumisest oma sõnumi mõlemad pooled. Rahvajutu kuulaja (või selle tekstivormis kirjapaneku lugeja) saab teada ainult ühe osapoole interpretatsiooni või selle derivaadid. Juhul, kui katkuvaimuks peetud olend oli tegelikkuses siiski tavaline inimene, kujunes tal vastaspoole kummalist käitumist - näiteks füüsilise rünnaku katseid või rituaalset põrandal magamist - nähes tõenäoliselt toimuva kohta oma tõlgendus (nt oletus, et nähtud inimesed on purjus või jampsivad haiguse käes), mis katkumuistendina meieni ei jõua, aga võis mingis teises pärimuskontekstis samuti areneda rahvajutuks. Samamoodi võis kurjas silmas kahtlustataval inimesel, kes tegelikult ise ei püüdnud kedagi sihilikult kaetada, tekkida oma tõlgendus sellest, kui mõni kaasinimene talle äkki tõrjemaagilisel eesmärgil tagumikku näitas või soola järele viskas. Näiteks võis ta neid mitteverbaalseid akte potentsiaalselt omakorda tõlgendada - vastavalt usundilisele traditsioonile, mille kohaselt oli võimalik selliste tegude kasutamine ka kahjustaval eesmärgil - musta maagia katsena. Raskesti mõistetava tegevuse maagilist seletamist toetas omakorda tõik, et maagilised võtted ei eksisteerinud sugugi ainult usundi- ja jutumaailmas, vaid - nagu mitmed autorid on rõhutanud (vrd nt Bever 2013: 38jj) - neid praktiseeriti modernismieelses ühiskonnas, aga mõnevõrra hiljemgi tõepoolest ka päriselus. Käesoleva artikli raamidest jääb välja tahtlikult maagilist efekti taotleva mitteverbaalse käitumise (näiteks taotlusliku pilguga kaetamise) kujutamine usundilistes juttudes, mille kirjeldamist kohtab iseenesest samuti üpris sageli.

Järgnevas memoraadis on põgusalt ära toodud kaks mitteverbaalse käitumise episoodi: 1) noormees pakkus meeldivale tüdrukule kringlit; 2) koer nuuskis 
inimest saba alt. Kogeja seab need tegevused armumaagiaga seotud uskumuste raamistusse ja lisab oma usundilistel eelteadmistel põhineva tõlgenduse. Verbaliseeritud tekst on traditsioonisidus ja välistab võimaluse, et noormees võis neiule kringlit pakkuda ka ilma maagilise tagamõtteta või et koerad võivad inimesi nuuskida ka ilma eelnevalt maagilisi aineid sisse söömata.

Eks ennemalt ikke tehtud neid tükka, süedeti nõidust sisse. Üks poiss tahi minu, andis mulle laadal kringli, ilus saiakringel. Ei mina söönd, viskasin Võtikvere jõkke. Kui koerale annad, siis kuer akkab järele käima, mitte maha ei jää. Mul omal õli tüdrik. Kuer õli selle tehtud kaku ära söönud, ei enam saand kudagi, mudku ajasin tüdriku minema. Kuer käis järsku järel ja nuuskis saba alt (ERA II 193, 113/4 (108) < Torma khk, 1938).

Seega sobib siinkohal parafraseerida järgnevat Mihhail Lotmani võrdlust, asendades 'mälu' 'mitteverbaalse käitumisega': "Mälu võib võrrelda pigem mustkunstniku kübaraga, kuhu pannakse rätik, välja aga võetakse küülik. Vahe on vaid selles, et inimene/kultuur on siiralt arvamusel, et just küülik oligi sinna pandud, ning üllatust pakub nimelt rätiku rekonstrueerimine" (Lotman 2012: 182-183), kuna mitteverbaalse käitumise tõlgendusprotsess usundilistes juttudes võib esile kutsuda samavõrd suuri tähendusnihkeid.

\section{Lõpetuseks}

Nagu eeltoodud analüüs näitas, vahendavad usundilised jutud enamat kui narratiivses vormis edasiantud mitteverbaalse sündmuse täpse kirjelduse. Inimest tajumise hetkel mõjustav teave hõlmab nii juba varasemast olemasolevaid kujutelmi kui ka antud hetkel kogetavat olukorda ja selle tõlgendusi. Mitteverbaalse käitumise mõistmine toimub seega kogeja varasema, valdavalt verbaliseeritud vormis omandatud usundilise teadmuse valguses. Nii verbaalsel kui ka mitteverbaalsel sündmusel põhinevad narratiivid kujutavad endast pigem mingi olukorra või kogemuse tõlgendust või töötlust, mille käigus iseendast tähendusetu sündmus võib saada uue, usundilises mõttes olulise tähenduse, omandades narratiivses traditsioonis edasilevimiseks sobiva vormi. Tõenäoliselt just seetõttu, et mitteverbaalse käitumise puhul on usundiline tõlgendamisruum sedavõrd avar, kasutavad kogejad ja jutustajad teatavaid korduvaid konkretiseerivaid mudeleid, näiteks tundub esmane mitteverbaalse teabe töötlus toimuvat baaskriteeriumide: võõras-tuttav, üleloomulik-loomulik, ohtlik-mitteohtlik baasil ning tulemustest sõltuvalt järgneb kas neutraalne reaktsioon, passiivsemate kaitsemeetmete või otseselt agressiivse käitumise kasutamine. Ei saa väita, et absoluutselt kõiki selliseid mitteverbaalset komponenti sisaldavaid rahvajutte 
on tingimata ajendanud kellegi reaalne mitteverbaalne kogemus, ent see polegi antud kontekstis tähtis. Huvi pakub pigem asjaolu, et rahvajuttu on nimelt sellisena peetud narratiivse koherentsuse reeglitele vastavaks, mistõttu see on saanud siseneda jututraditsiooni.

Ka tänapäevaste usundiliste juttude puhul saab öelda, et neis kirjeldatud mitteverbaalse käitumise tõlgendamisel lähtutakse folkloorsetest eelteadmistest, interpreteerides mitteverbaalseid signaale edastavaid varjukogusid näiteks surnuvaimu, painaja, kaitseingli või pahatahtliku kaetajana ning võttes vajadusel appi usundilised kaitsemehhanismid. Lisandunud on meedia mõju komponent: näiteks hääletajafolklooris esineb jutte, milles suhtlusakt koosneb ainult autojuhi vaikimisest ja hääletaja antud tõlgendusest selle kohta, kusjuures kogu jutt võib olla üles ehitatud hääletaja ootusele, et juht, kes "näeb välja nagu gangsterifilmis" või "nagu zombi”, vastavalt käituks. Ent nii tugeva eelhäälestuse korral ei olegi vajalik, et autojuht midagi ütleks või teeks, memoraat temast on juba sündinud. Mitteverbaalse sündmuse mõtestab ja selles osalenud isikute staatuse määrab seega jutustaja, kusjuures verbaliseerimisel tehtavate valikute juures mängib olulist rolli sündmuse toimumise kontekst (näiteks kutsuvad ohustavana või ebatavalisena tajutud kontekstid sagedamini esile üleloomulikke tõlgendusi) ja sündmuses osalenud isikute tegutsemise laad (näiteks jätab isikute vaikimine jutustajale avaramad tõlgendusraamid).

Muutused usundis ja teemaepohhide vaheldumine massimeedias avalduvad operatiivselt ka mitteverbaalsete sündmuste tõlgendamises: näiteks samamoodi, nagu meediakajastustes on viimastel kümnenditel vähenenud tulnukate ja tulnukalaevade osakaal, kohtab neid vähem ka usundilistes juttudes. Mitteverbaalse käitumise tõlgendamise protsess ise aga ei näi olevat usundilistes juttudes muutunud. Kommunikatsiooni-ja narratiiviteooriad pakuvad usundiliste juttude mitteverbaalse aspekti vaatlemisele olulise raami ja hõlbustavad kirjeldatud tõlgendusprotsesside analüüsimist, kuid nagu võis juba prognoosida, sobivad need sellises kontekstis rakendamiseks ainult teatavate mööndustega. Näiteks ei kehti usundiliste juttude puhul sageli kommunikatsiooni sihipärasuse ja mõlemapoolsuse printsiip, vaid pigem toimub mitteverbaalse sündmuse ühepoolne usundiline tõlgendamine.

\section{Kommentaar}

1 Artikli valmimist toetasid institutsionaalse uurimistoetuse projektid IUT 22-5 ja IUT 2-43. 


\section{Käsikirjalised allikad}

Kursiivis esitatud pärimustekstid on pärit Eesti Kirjandusmuuseumist:

E - Matthias Johann Eiseni käsikirjaline rahvaluulekogu aastaist 1880-1934.

ERA II - Eesti Rahvaluule Arhiivi rahvaluulekogu.

\section{Kirjandus}

Arukask, Madis 2003. Eksimine vadja ja setu rahvakultuuris ning folkloorse etteantuse osa selles. Kõiva, Mare (toim). Artikleid usundi- ja kombeloost. Sator 2. Tartu: EKM Teaduskirjastus, lk 96-112 (http://www.folklore.ee/rl/pubte/ee/sator/sator2/Eksimine. html - 15. oktoober 2015).

Benoit, William L. 1988. Review. Human Communication as Narration: Toward a Philosophy of Reason, Value, and Action, by Walter R. Fisher. Argumentation 2 (4), lk 535-538.

Berger, Charles R. \& Calabrese, Richard J. 1975. Some Exploration in Initial Interaction and Beyond: Toward a Developmental Theory of Communication. Human Communication Research 1, lk 99-112.

Bever, Edward 2013. The realities of witchcraft. Culture, cognition and everyday life. Basingstoke: Palgrave Macmillan.

Blacker, Carmen 1990. The Folklore of the Stranger: A Consideration of a Disguised Wandering Saint. Folklore 101/2, lk 162-168 (doi: 10.1080/0015587X.1990.9715790).

Bruner, Jerome 1991. Acts of Meaning. Cambridge: Harvard University Press.

Calero, Henry H. 2005. The Power of Nonverbal Communication. Aberdeen: Silver Lake Publishing.

Dundes, Alan 2007. On Game Morphology. A study of the structure of non-verbal folklore. Bronner, Simon J. (toim). The Meaning of Folklore. The Analytical Essays of Alan Dundes. Utah: Utah State University Press, lk 154-163.

Durkheim, Emile 1982. The Rules of Sociological Method. New York: The Free Press. [Esmatrükk 1895.]

Fisher, Walter R. 1987. Human Communication as Narration: Toward a Philosophy of Reason, Value, and Action. Columbia: University of South Carolina Press.

Giri, Vijai N. 2009. Nonverbal communication theories. Littlejohn, Stephen W. \& Foss, Karen A. (toim). Encyclopedia of Communication Theory. Thousand Oaks: SAGE Publications (http://dx.doi.org/10.4135/9781412959384.n262).

Hiiemäe, Reet 1997. Eesti katkupärimus. Monumenta Estoniae Antiquae II. Mütoloogilised haigused I. Tartu: EKI folkloristika osakond, Eesti Rahvaluule Arhiiv.

Hiiemäe, Reet 2007. Kollektiivsete hirmudega toimetulekust rahvapärimuses. Kõiva, Mare (toim). Artikleid usundi- ja kombeloost. Sator 6. Tartu: EKM Teaduskirjastus, lk 198-212 (www.folklore.ee/rl/pubte/ee/sator/sator6/ - 12. november 2015). 
Honko, Lauri 1972. Uskontotieteen näkokulmia. Helsinki: WSOY.

Hufford, David J. 1989. The Terror That Comes in the Night. An Experience-Centered Study of Supernatural Assault Traditions. Philadelphia: University of Pennsylvania Press.

Hutto, Daniel D. 2008. Folk Psychological Narratives. The Sociocultural Basis of Understanding Reasons. Massachusetts: Massachusetts Institute of Technology.

Kapper, Sille 2013. Muutuv pärimustants: kontseptsioonid ja realisatsioonid Eestis 2008-2013. Doktoriväitekiri. Tallinn: Tallinna Ülikool, Eesti Humanitaarinstituut (http://e-ait.tlulib.ee/341/1/kapper_sille.pdf - 15. oktoober 2015).

Kendon, Adam 1981. Introduction: Current Issues in the Study of "Nonverbal Communication”. Kendon, Adam (toim). Nonverbal Communication, Interaction, and Gesture. Approaches to Semiotics. Haag: Mouton Publishers, lk 1-56.

Kimmel-Tenjes, Silvi 1993. Mitteverbaalsest kommunikatsioonist. Akadeemia 3, lk 535560 .

Kõuts-Klemm, Ragne 2007. Inimeseta teooria: Sissejuhatus Niklas Luhmanni autopoieetilistesse sotsiaalsetesse süsteemidesse. Akadeemia 11 (224), lk 2412-2442.

Laagus, Aino 1973. Situatsioonianalüüsist folkloristikas. Keel ja Kirjandus 7, lk 404-412.

Lintrop, Aado 2014. Suuline pärimus uskumuste kujundajana. Loomisaja lood. Uurimusi ja tõlkeid Põhja-Euraasia rahvaste usundist. Eesti Rahvaluule Arhiivi toimetused. Tartu: EKM Teaduskirjastus.

Lotman, Mihhail 2012. Struktuur ja vabadus. I: Semiootika vaatevinklist. 1.1. TartuMoskva koolkond: Tekstist semiosfäärini. Bibliotheca controversiarum. Tallinn: Tallinna Ülikooli Kirjastus.

Luhmann, Niklas 1984. Soziale Systeme: Grundriss einer allgemeinen Theorie. Frankfurt a.M.: Suhrkamp.

Luhmann, Niklas 1997. Die Gesellschaft der Gesellschaft 1-2. Frankfurt a.M.: Suhrkamp (https://steffenroth.files.wordpress.com/2012/03/gesellschaft-der-gesellschaft. pdf-15. oktoober 2015).

Novik, Jelena 2002. Hääle semiootilised funktsioonid Siberi rahvaste folklooris ja uskumustes. Mäetagused 19, lk 105-124 (doi: 10.7592/MT2001.19.novik).

Pentikäinen, Juha 1978. Oral transmission of knowledge. Dorson, Richard M. (toim). Folklore in the Modern World. World Anthropology. Haag: deGruyter.

Stark, Laura 2015. Voicelessness and the Limits of Agency in Early Modern Finnish Narratives on Magic and the Supernatural. Narrative Culture 2 (1), artikkel 6 (http:// digitalcommons.wayne.edu/narrative/vol2/iss1/6/ - 16. oktoober 2015).

Streeck, Jürgen \& Knapp, Mark L. 1992. The Interaction of Visual and Verbal Features in Human Communication. Poyatos, Fernando (toim). Advances in Non-Verbal Communication: Sociocultural, clinical, esthetic and literary perspectives. Amsterdam \& Philadelphia: John Benjamins Publishing Company, lk 3-23. 
Tenjes, Silvi 2004. Kategooriad inimese kognitiivsel ja sotsiokultuurilisel maastikul. Metslang, Helle \& Langemets, Margit \& Sepper, Maria-Maren (toim). Eesti Rakenduslingvistika Ühingu aastaraamat 1, lk 155-170 (http://dx.doi.org/10.5128/ERYa1.08).

Tenjes, Silvi 2014. Multimodaalne suhtlus ja kognitsiooniuuringud pedagoogikas. Eesti ja soome-ugri keeleteaduse ajakiri 5, nr 3, lk 115-132 (http://dx.doi.org/10.12697/ jeful.2014.5.3.06).

Valk, Ülo 1994. Eesti rahvausu kuradi-kujutelm kristliku demonoloogia ja rahvusvahelise folkloori kontekstis: ilmumiskujud. Dissertationes philologiae estonicae Universitatis Tartuensis. Doktoriväitekiri. Tartu: Tartu Ülikooli Kirjastus.

Valk, Ülo 2015. Magic, Participation and Genre: Narrative Experiences of the Supernatural. Espak, Peeter \& Läänemets, Märt \& Sazonov, Vladimir (toim). When gods spoke. Researches and reflections on religious phenomena and artefacts. Tartu: University of Tartu Press, lk 415-430.

Voolaid, Piret 2011. Eesti mõistatused kui pärimusliik muutuvas kultuurikontekstis. Dissertationes folkloristicae Universitatis Tartuensis. Doktoriväitekiri. Tartu: Tartu Ülikooli Kirjastus.

Weisbuch, Max \& Ambady, Nalini 2008. Non-Conscious Routes to Building Culture: Nonverbal Components of Socialization. Journal of Consciousness Studies 15, lk 159-183.

\title{
Summary
}

\section{Nonverbal event as part of belief narrative}

\author{
Reet Hiiemäe
}

Keywords: belief narrative, narration, nonverbal behaviour, nonverbal communication

A communicative act that involves the presence of two or more persons always contains a nonverbal aspect. The focus of the article is on nonverbal situations as a basis for the evolution of belief narratives. This pre-narrative aspect has not received much attention in narrative research as most analyses are based on texts that already exist in verbalised form. However, on many occasions the basis for a belief narrative is a nonverbal act that has triggered its witness or re-narrator(s) to interpret it in the framework of a vernacular belief. Hence, texts that contain a nonverbal part consist of two components: 1) description of a nonverbal occurrence; 2 ) its meaning/interpretation that is verbalised by the narrator in the framework of a topical belief tradition. By bringing examples from Estonian belief narratives, the author points out some models and patterns that leap to the eye in texts narrating about nonverbal occurrences (e.g. the context of described situations, the types and results of activities described, etc.). As a theoretical basis, works on communication theory and vernacular belief research are used. 